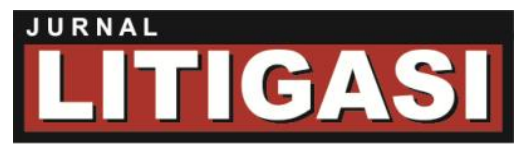

Available online at: http://ejournal.unpas.ac.id/index.php/litigasi

Litigasi, Vol. 18 (1), 2017,

DOI: http://dx.doi.org/10.23969/litigasi.v18i1.573

\title{
KEDUDUKAN UNIDROIT SEBAGAI SUMBER HUKUM KONTRAK DALAM PEMBAHARUAN HUKUM KONTRAK INDONESIA YANG AKAN DATANG
}

\section{N. Ike Kusmiati}

Fakultas Hukum Universitas Pasundan Bandung, Jl. Lengkong Besar 68 Bandung Tlp : (022) 7536717, Hp : 081328014790 , Email : ike.kusmiati@unpas.ac.id

\begin{abstract}
ABSTRAK
Transaksi bisnis sering kali dihadapkan pada persoalan memastikan bahwa hak dan kewajiban para pihak akan dilaksanakan sebagaimana yang diperjanjikan. Dalam praktik terjadi persoalan para pihak tidak memenuhi perjanjian sebagaimana yang diperjanjikan, terlebih lagi ketika menghadapi kesulitan hak dan kewajiban para pihak karena berada di negara yang berbeda, dengan sistim hukum yang berbeda pula. Oleh karenanya untuk menjawab permasalahan tersebut para pihak akan mencari sumber hukum, yaitu Buku III KUHPerdata disamping mempelajari dan memahami prinsip hukum kontrak komersial internasional yaitu UNIDROIT yang memuat prinsip-prinsip yang dapat diadopsi sebagai salah satu karya yang mengupayakan standarisasi prinsip hukum kontrak guna mendorong harmonisasi hukum komersial internasional, sebagai upaya mempertemukan para pelaku bisnis antar negara yang berbeda, sehingga diperlukan landasan hukum yang sama dalam pembaharuan hukum kontrak Indonesia yang akan datang.
\end{abstract}

Kata kunci : Kedudukan, UNIDROIT, Hukum, Kontrak, Indonesia.

\begin{abstract}
[Unidroited Position As A Source Of Contract Law In The Future Of Indonesian Contract Law Amandement] In business transaction often faced the issue of ensuring that the rights and obligation are fulfilled as the agreement as agreed, especially when facing the difficulties of the rights and obligation of the parties due to different legal system between countries. Thereore, to answer the problems the parties will seek legal sources, namely book III of the Civil Code in addition to studying and understanding the principles of internasional commercial contract law, namely UNIDROIT which contains principles that can be adopted as one of the works that seek Standarization of contract law to encourage the harmonization of commercial law international efforts to bring together different business actors between countries, so that the same legal basis is required in the coming renewal of Indonesia contract law.
\end{abstract}

Keyword : Position, UNIDROIT, Law, Contract, Indonesia. 
Available online at: http://ejournal.unpas.ac.id/index.php/litigasi

Litigasi, Vol. 18 (1), 2017,

DOI: http://dx.doi.org/10.23969/litigasi.v18i1.573

\section{PENDAHULUAN}

Indonesia tidak dapat mengabaikan pengaruh hubungan ekonomi dan bisnis antar negara yang saling memiliki ketergantungan dan saling berpengaruh terhadap hukum kontrak yang berlaku saat ini, terjadinya pola hubungan sosial, politik ekonomi dewasa ini dapat menimbulkan masalah baru dalam hubungan kontraktual antara para pihak.

Berbagai perjanjian seperti WTO (World Trade Organization) atau AFTA (ASEAN Free Trade Area) telah menggariskan ketentuan-ketentuan hukum yang memaksa (mandatory law) yang harus dipatuhi Indonesia antara lain untuk melaksanakan berbagai standar yang seragam berlaku juga dinegara lain.

Tulisan ini ingin melihat perkembangan dan kedudukan prinsip hukum UNIDROIT yang dapat berguna bagi pembaharuan hukum kontrak di Indonesia, sebagaimana disarankan oleh Ferronica Taylor (Soenandar, 2004a) menyarankan agar hukum kontrak Indonesia yang akan datang agar memperhatikan prinsipprinsip hukum kontrak UNIDROIT. Oleh karena persoalan yang dihadapi secara umum masih berpegang teguh pada KUHPerdata yang berlandaskan pada prinsip kebebasan berkontrak yang merupakan peninggalan Napoleon yang dalam beberapa hal sudah ketinggalan karena di Belanda sendiri Burgerlijke Wetboek sudah diganti dengan New Burgerlijke Wetboek yang isinya telah disesuaikan dengan prinsip-prinsip UNIDROIT.

Persoalan bisnis dan ekonomi saat ini semakin bersifat transnasional dipicu oleh percepatan teknologi,yang menimbulkan permasalah baru. Prinsipprinsip UNIDROIT adalah prinsip hukum yang mengatur hak dan kewajiban para pihak pada saat menerapkan kebebasan berkontrak, karena prinsip kebebasan berkontrak bila tidak diatur dapat membahayakan pihak yang lemah, walaupun disadari prinsip ini sifatnya fleksibel.

Hukum kontrak merupakan hukum yang sangat penting dalam era perdagangan bebas saat ini, dimana transaksi bisnis yang dilakukan antar individu maupun badan usaha termasuk negara dilakukan dengan pembuatan kontrak,

Copyright (C) 2017, LITIGASI, p-ISSN: 0853-7100; e-ISSN: 2442-2274 
baik dalam skala nasional maupun skala kontrak internasional. Kontrak merupakansuatu jaminan kepastian hukum bagi para pihak yang membuatnya, apabila dilaksanakan dengan itikad baik dan didukung oleh hukum yang mengatur mengenai kontrak (Chandrawulan, 2016b).

Berdasarkan pada Pasal II Aturan Peralihan Undang-Undang Dasar Negara Republik Indonesia Tahun 1945, bahwa hukum kontrak yang terdapat dalam Buku III KUHPerdata (Burgerlijk Wetboek) masih berlaku hingga saat ini, sebelum ada pengaturan lebih lanjut mengenai hukum kontrak di Indonesia (UUD 1945, 1945). Sejalan dengan perkembangan hukum kontrak dewasa ini dalam kondisi pasar bebas, dimana hukum kontrak Indonesia berasal dari Civil Law yang pada kenyataannya tidak dapat lagi diterapkan secara utuh. Sementara kaedah-kaedah hukum yang berasal dari system hukum Commom Law dan Hukum Islam saat ini sudah banyak mempengaruhi pembangunan hukum khususnya hukum bisnis di Indonesia (Chandrawulan, 2016c).

Perbandingan hukum kontrak di negara Belanda sebagai tempat asalnya KUHPerdata Buku III Indonesia telah banyak mengalami perubahan dengan nama New Burgerlijk Wetboek (NBW) dimana secara substansi telah mengalami perubahan yang signifikan berbeda dengan Burgerlijk Wetboek Indonesia, baik dari aspek substansi maupun sistematika sebagai perbaikan atas kelemahankelemahan yang terdapat dalam BW Indonesia. New Burgerlijk Wetboek bahkan telah maju dengan mengadopsi sistem hukum kontrak Common Lawdalam mewujudkan kepastian hukum dalam kontrak .

Di sisi lain komitmen Indonesia untuk berperan dalam perdagangan bebas membutuhkan harmonisasi hukum dengan memperhatikan hukum yang memaksa secara Internasional. Akan tetapi dalam pelaksanaannya penerapan terhadap hukum memaksa tersebut dapat menjadi kendala, karena di satu sisi masyarakat Indonesia belum dapat bersaing secara ketat, dimana di sisi lain harus dapat mengikuti kebutuhan bisnis dengan menerapkan standar yang berlaku (Soenandar, 2004b).

Copyright $\odot$ 2017, LITIGASI, p-ISSN: 0853-7100; e-ISSN: 2442-2274 
Oleh karenanya Indonesia harus melakukan penyesuaian dengan aturan yang berlaku, di samping melalui penyusunan kontrak-kontrak yang seimbang dan berkeadilan melalui intensitas transaksi bisnis dan pembaharuan hukum melalui kontrak, penyelesaian perselisihan, dan pembentukan hukum kontrak di Indonesia.

Saat ini keberadaan Buku III KUHPerdata sudah usang dimana sejak diundangkan 1 Mei 1848 hingga sekarang masih berlaku. Menurut Mentri Sahardjo menyatakan bahwa Burgerlijk Wetboek (BW) bukan lagi sebagai "Wetboek" tetapi sebagai "Rechtboek" yang hanya digunakan sebagai pedoman saja. Keadaan hukum kontrak dalam Buku III BW sudah tidak dapat menampung perkembangan kepentingan kontrak dalam praktek yang sudah berkembang, dimana hubungan para pihak sudah melintas batas negara, dengan system hukum yang kompleks.

Telah berkembangnya perjanjian internasional, yang bersifat multinasional seperti GATT/WTO juga secara Regional AFTA serta APEC ini telah membuka akses perdagangan dan bisnis yang tidak hanya antar pengusaha di Indonesia, tetapi juga terjadi antara pengusaha diantara negara-negara yang berbeda system hukumnya. Perkembangan transaksi dan bisnis tersebut begitu cepat yang sekarang telah terjadi melalui elektronik atau disebut e-commerce sebagai bentuk model bisnis yang tidak dilakukan melalui tatap muka secara fisik. Disamping itu telah berkembang pula kontrak-kontrak bisnis yang dibuat secara baku atau standar kontrak yang tumbuh begitu cepat, dan hampir semua kontrak dalam perkembangannya mengikuti standar kontrak tersebut.

Perkembangan kontrak bisnis baik yang terjadi karena berkembangnya kontrak maupun karena kecanggihan kontrak, dengan demikian hal ini belum dapat dijangkau oleh hukum kontrak yang terdapat dalam Buku III KUHPerdata Indonesia tentang perikatan, sehingga masih dibutuhkan ketentuan hukum kontrak yang mampu menjangkau kepentingan para pihak dalam bertransaksi secara nasional maupun internasional yang dapat memberi kepastian hukum

Copyright $\odot$ 2017, LITIGASI, p-ISSN: 0853-7100; e-ISSN: 2442-2274 
kepada para pihak. Tumbuh dan berkembangnya bentuk-bentuk dan prinsipprinsip hukum kontrak tidak terlepas dari 3 faktor yang mempengaruhinya, yaitu (Syaifuddin, 2012):

1. Faktor internal,yaitu faktor kebijakan pemerintah dalam memakmurkan negara dan rakyat, sehingga turut campur dalam bidang ekonomi, dengan dikeluarkannya berbagai regulasi.

2. Faktor eksternal, yaitu faktor luar negeri yang menjadikan perekonomian nasional makin terbuka, akibat arus globalisasi perekonomian dunia, sehingga unsur-unsur asing mempengaruhi system hukum nasional, dengan dibukanya pasar bebas dan investasi asing yang menimbulkan tidak adanya hambatan dalam berbisnis secara internasional.

3. Meningkatnya frakuensi aneka macam bentuk kontrak baku, sehingga sehingga intensitas kegiatan pembuatan kontrak makin banyak.

Sistem hukum kontrak yang berlaku di dunia secara universal, dalam perkembangannya terdapat dua, yaitu ketentuan-ketentuan mengenai prinsipprinsip hukum kontrak komersial internasional sebagai standar secara internasional, yang dibuat oleh UNIDROIT (Principles of International Commercial Contract) dan ketentuan universal mengenai jual beli dagang internasional yang diatur oleh konvensi yang dikeluarkan oleh Perserikatan Bangsa-Bangsa yaitu The United Nations Convention on Contracts for the Internasional Sale of goods (Chandrawulan, 2016d).

Berdasarkan pengaturan dalam ketentuan-ketentuan tersebut, berkaitan dengan prinsip-prinsip yang berlaku di dalamnya, dapat dimasukan ke dalam hukum kontrak nasional, yang akan datang untuk mengisi kekosongan hukum dalam pengaturan hukum kontrak yang akan datang, Oleh karenanya kedua pengaturan berdasarkan kedua system hukum tersebut memuat dasar-dasar dan prinsip-prinsip hukum kontrak secara universal, baik dalam system hukum Civil Law maupun Common Law system.

Copyright $\odot$ 2017, LITIGASI, p-ISSN: 0853-7100; e-ISSN: 2442-2274 
Pentingnya pengaturan kontrak secara internasinal, dimana prinsip-prinsip kontrak internasional UNIDROIT tahun 1994 (yang pertama) yang direvisi tahun 2004 atau edisi kedua yang kemudian direvisi tahun 2010 atau edisi ketiga adalah sumber hukum kontrak yang penting disamping CISG 1980 (Adolf, 2011). UNIDROIT berupaya agar terwujudnya suatu harmonisasi hukum atau ketentuan-ketentuan dalam perdagangan internasional, sehingga berbagai aturan dalam perdagangan internasional yang berbeda antara satu system hukum dengan system hukum lainnya, atau terjadi kendala bagi para pihak yang melalukan transaksi perdagangan internasional, dapat dijembatani oleh UNIDROIT.Sebagaimana dianut dalam UNIDROIT akan membawa pengaruh positif dalam pembentukan hukum kontrak di Indonesia yang akan datang, yang menjadi standarisasi prinsip hukum kontrak karena pengaruh hukum asing terhadap praktik hubungan kontraktual diberbagai negara termasuk Indonesia tidak dapat lagi dihindari terjadinya berbagai intensitas hubungan keperdataan dalam kontrak komersial, sehingga pembaharuan hukum kontrak nasional atau hukum perjanjian nasional yang akan datang dalam penerapan prinsip-prinsip hukum internasional yang akan datang yang terdapat dalam UNIDROIT akan menjadi bagian terpenting dari tujuan penelitian ini. Berdasarkan apa yang sudah penulis uraikan, untuk memudahkan dalam pembahasan tullisan ini, penulis membatasi dalam 2, persoalan, yaitu bagaimana kedudukan UNIDROIT sebagai sumber hukum kontrak dalam pembaharuan hukum kontrak Indonesia yang akan datang dan bagaimana persamaan dan perbedaan diantara hukum kontrak Indonesia dengan hukum kontrak berdasarkan UNIDROIT.

Copyright $\odot$ 2017, LITIGASI, p-ISSN: 0853-7100; e-ISSN: 2442-2274 


\section{PEMBAHASAN}

\section{A. Kedudukan UNIDROIT}

Sebagai sumber hukum kontrak dalam pembaharuan hukum kontrak Indonesia yang akan datang sangat signifikan dengan kondisi perkembangan kontrak di Indonesia dan dimanca Negara. Pengaturan tentang kontrak di Indonesia masih mengacu pada ketentuan Buku III KUHPerdata yang merupakan produk Belanda sampai sekarang masih berlaku, termasuk ketentuan-ketentuan peninggalan jaman Belanda sampat saat ini masih berlaku, sebagaimana ketentuan dalam Pasal II Aturan Peralihan UndangUndang Dasar 1945, berkenaan dengan kontrak masih berlaku.

Keberadaan KUHPerdata menurut mentri Sahardjo, bahwa KUHPerdata bukan lagi sebagai "Wetboek" tetapi sebagai "Rechtboek" yang dipakai sebagai pedoman belaka bahkan pakar hukum Adat Indonesia, Mahadi menyetujui gagasan tersebut dan menyatakan bahwa KUHPerdata sebagai kodifikasi tidak berlaku lagi dan yang masih berlaku adalah aturanaturan yang tidak bertentangan dengan semangat dan suasana kemerdekaan (Hernoko, 2009a). Gagasan yang menganggap KUHPerdata bukan lagi sebagai undang-undang mendapat sambutan positif dan persetujuan bulat pada konggres Majelis IImu Pengetahuan Indonesia II di Yogyakarta pada bulan Oktober tahun 1962. Kemudian gagasan inipun diperkuat oleh Mahkamah Agung dengan mengeluarkan Surat Edaran Mahkamah Agung (SEMA) No. 3 Tahun 1963 tanggal 5 September yang ditujukan kepada Pengadilan Tinggi dan Pengadilan Negeri di seluruh Indonesia (Chandrawulan, 2016a).

Walaupun Surat Edaran Mahkamah Agung tersebut menurut teori ilmu hukum bukan sebagai sumber hukum formal, sehingga tidak bisa menyatakan tidak berlakunya pasal undang-undang, tetapi menurut Subekti SEMA No. 3 Tahun 1963 tersebut harus dipandang sebagai anjuran kepada para hakim agar jangan ragu-ragu dan takut-takut mengesampingkan

Copyright $\odot$ 2017, LITIGASI, p-ISSN: 0853-7100; e-ISSN: 2442-2274 
ketentuan-ketentuan KUHPerdata/BW mengenai perikatan, manakala mereka berpendapat bahwa ketentuan KUHPerdata/BW sudah tidak sesuai lagi dengan rasa keadilan masyarakat (Chandrawulan, 2016a).

Kondisi Buku III KUHPerdata/BW tentang perikatan dalam sistem hukum Indonesia hingga sekarang masih menjadi suatu ganjalan, karena sudah tidak sesuai dengan kondisi dan perkembangan sekarang, dimana kontrak bisnis yang terjadi dalam masyarakat begitu cepat berkembang, disamping terjadinya hubungan antar para pihak, baik secara nasional maupun internasional sangat memerlukan pengaturan. Bahwa globalisasi ekonomi mendorong harmonisasi hukum komersial internasional, dimana para pelaku bisnis antar warga negara yang berbeda akan saling bertemu, oleh karenanya diperlukan landasan yang sama, sehingga berbagai aturan hukum asing akan berpengaruh terhadap pelaksanaan kontrak di Indonesia (Risdiana, 2016). Sebagai dasar hukum masih berlakunya Kitab UndangUndang Hukum Perdata/BW di Indonesia adalah Pasal II Aturan Peralihan UUD 1945, bahwa segala badan dan segala lembaga yang ada masih berlaku sebelum adanya badan atau lembaga yang baru. Hal ini tidak lain adalah untuk mengisi kekosongan hukum (rechtvacuum), karena sampai saat ini belum ada undang-undang sebagai aturan khusus yang mengatur tentang kontrak di Indonesia. Buku IIIKUHPerdata sebagai hukum pelengkap berdasarkan pada asas kebebasan berkontrak sebagaimana diatur dalam Pasal 1338 ayat (1) KUHPerdata merupakan representasi dari penghormatan terhadap hak-hak asasi manusia (human right), khususnya hak ekonomi right (Chandrawulan, 2016a). Ini berarti bahwa hukum kontrak memberikan kebebasan kepada para pihak untuk membuat kontrak yang dapat mengakomodasi, memfasilitasi dan mengatur kepentingan hak dan kewajiban yang disepakati bersama oleh para pihak, yang berakibat hukum mengikat para pihak, bahkan berlaku sebagai undang-undang bagi para pihak yang membuatnya (Syaifuddin, 2012).

Copyright $\odot$ 2017, LITIGASI, p-ISSN: 0853-7100; e-ISSN: 2442-2274 
Sifat hukum kontrak sebagai hukum pelengkap, ini juga berarti bahwa norma-norma atau aturan-aturan yang berada dalam hukum kontrak boleh disimpangi para pihak, sehingga para pihak dapat membuat aturanaturan dalam kontrak sebagaimana yang dikehendaki dalam kontrak oleh para pihak, sepanjang tidak bertentangan dengan ketentuan yang sifatnya memaksa, berkenaan dengan ketentuan undang-undang, ketertiban umum dan kesusilaan dalam masyarakat.

Pembatasan kebebasan berkontrak sebagai upaya perlindungan terhadap hak-hak asasi manusia dari keadaan yang tidak pasti, tidak adil, tidak tertib, dan tidak bermoral yang merugikan para pihak yang membuat kontrak itu sendiri maupun pihak ketiga atau pihak lainnya (Syaifuddin, 2012).

Kontrak yang diatur secara khusus dalam Buku III KUHPerdata, Bab II tentang perikatan-perkatan yang dilahirkan dari kontrak dan Bab V sampai dengan Bab XVIII yang mengatur tentang perjanjian-perjanjian bernama yang dalam KUHPerdata memiliki nama khusus dan mempunyai nama tertentu dalam KUHPerdata. Begitu pula norma-norma kontrak yang diatur dalam Bab II Buku III tersebut, juga berlaku terhadap kontrak-kontrak yang tidak diatur secara khusus dan tidak mempunyai nama tertentu yang dikenal dengan sebutan perjanjian tidak bernama, sebagaimana diatur dalam Pasal 1319 KUHPerdata (Risdiana, 2016).

Pengaturan hukum perjanjian dalam Buku III KUHPerdata diatur mulai dari Pasal 1313 KUHPerdata tentang pengertian perjanjian sampai dengan Pasal 1381 KUHPerdata tentang hapusnya perikatan. Sesuai dengan perkembangan masyarakat perlu dibuat aturan-aturan berkenaan dengan kontrak yang belum diatur dalam Buku III KUHPerdata, sebagai upaya pemerintah dalam mengisi kekosongan hukum yang terjadi dari Buku III KUHPerdata tersebut, untuk memenuhi kebutuhan dalam praktik sesuai

Copyright $\odot$ 2017, LITIGASI, p-ISSN: 0853-7100; e-ISSN: 2442-2274 
dengan perkembangan yang terjadi, pemerintah menyusun berbagai peraturan perundang-undangan, berkaitan dengan kontrak.

Kekosongan hukum itu terjadi berkenaan dengan lahirnya transaksi melalui elektronik (transaksi e-commerce) yang saat ini tidak lagi dapat dijangkau oleh Buku III KUHPerdata, dimana perkembangan masyarakat untuk terlibat bertransaksi secara elektronik tidak lagi dapat dibendung dan dihindari. Sebagai akibat dari kemajuan teknologi dewasa ini akibat dari kecanggihan era digital. Dalam traksaksi bisnis model digital ini para pihak tidak langsung bertatap muka, termasuk dapat melakukan kesepakatan yang secara langsung, melainkan tidak dapat melakukan tanda tangan secara fisik sebagaimana kebiasaan pada umumnya.

Apabila dihubungkan dengan Buku III KUHPerdata terjadi persoalan ketika adanya masalah berkaitan dengan kesepakatan dan pembuktian. Banyak hal-hal yang terjadi dalam transaksi bisnis e-commerce yang tidak diatur dalam Buku III KUHPerdata, sehingga dalam praktik banyak perselisihan diantara para pihak, akibat adanya kekosongan hukum. Kekosongan hukum mengenai transaksi e-commerce diantaranya dapat diatasi dengan menggunakan doktrin atau pendapat para ahli yang juga berkedudukan sebagai sumber hukum dan juga penerapan Undang-Undang Tentang Transaksi Elektronik (Chandrawulan, 2016a).

Pengaturan yang tidak ada dalam Buku III KUHPerdata adalah pengaturan tentang itikad buruk dalam prakontraktual, karena ini penting dimana pada saat negosiasi sangat dibutuhkan sehingga dapat menghindari adanya pihak yang dirugikan, sehingga penting adanya pengaturan tentang itikad baik pada saat prakontraktual, baik berupa keterbukaan, kejujuran dari para pihak, sehingga para pihak dapat melaksanakan kontrak dengan adil dan adanya kepastian hukum bagi para pihak yang membuat kontrak. Bukankah merupakan angan-angan dengan kontrak sabagai upaya untuk meningkatkan kesejahteraan masyarakat. Pentingnya pengaturan tidak boleh mekukan itikad

Copyright @ 2017, LITIGASI, p-ISSN: 0853-7100; e-ISSN: 2442-2274 
buruk atau adanya kewajiban untuk melakukan itikad baik pada saat negosiasi dalam kontrak. Sementara pengaturan itikad baik dalam pelaksanaan perjanjian telah diatur dalam Buku III Pasal 1338 ayat (3) bahwa perjanjian harus dilaksanakan dengan itikad baik.

Hal lain yang juga belum diatur dalam Buku III KUHPerdata dan terjadi dalam praktik adalah pengaturan tentang penyalahgunaan keadaan (undue inpluence) yaitu terjadi dimana pihak yang kedudukannya secara ekonomi lebih tinggi, memanfatkan posisinya untuk memaksakan kehendaknya kepada pihak lawan, agar mengikuti kehendaknya. Hal ini jelas bertentangan dengan asas kebebasan berkontrak sebagaimana diatur dalam Pasal 1338 ayat (1) KUHPerdata.

Mengenai faktor-faktor yang menyebabkan cacat kehendak ini dalam Buku III KUHPerdata telah diatur dalam Pasal 1321 KUHPerdata bahwa “Tiada sepakat yang sah apabila sepakat itu diberikan karena kekhilafan, atau diperolehnya dengan paksaan atau penipuan". Hal ini ternyata belum dapat mengakomodir bila terjadinya penyalahgunaan keadaan (undue influence) dalam praktik. Oleh karenanya apabila ada unsur undue influence, dalam kontrak, dengan sendirinya para pihak dapat mengajukan pembatalan terhadap berjalannya kontrak tersebut, karena undue influence termasuk unsur subjektif sebagaimana juga berlaku terhadap unsur-unsur kekhilafan, paksaan atau penipuan. Oleh karenanya diperlukan pengaturan tentang undue influence ini sebagai perlindungan terhadap pihak yang dirugikan (Hernoko, 2009b).

Prinsip-prinsip kontrak UNIDROIT telah mengalami tiga kali perubahan, yaitu tahun 1994 sebagai edisi pertama yang menyoroti tentang kodifikasi hukum umum internasional kontrak komersial, menerbitkan Principle of International Commercial Contract (PICC) yang berisi tentang ketentuan-ketentuan umum tentang masalah-masalah hukum kontrak yang terjadi pada semua jenis kontrak, interpretasi kontrak, validitas atau

Copyright $\odot$ 2017, LITIGASI, p-ISSN: 0853-7100; e-ISSN: 2442-2274 
berlakunya suatu kontrak yang anti kerugian apabila kewajiban dalam suatu kontrak tidak dilaksanakan (Chandrawulan, 2016a).

Edisi kedua yang direvisi tahun 2004 dari PICC adalah berkaitan dengan pengaturan hukum kontrak umum, seperti pembatasan periode kontrak dan kontrak untuk kepentingan pihak ketiga. Revisi ketiga pada tahun 2010 meliputi antara lain illegality, pernyaratan kontrak, tanggungjawab bersama dan terpisah (Chandrawulan, 2016a).

UNIDROIT dirancang agar tercipta suatu harmonisasi hukum dalam perdagangan internasional, agar perbedaan system hukum dengan system hukum lainnya tidak menjadi rintangan bagi para pihak dalam melakukan transaksi perdagangan internasional. UNIDROIT berupaya meletakan aturan hukum kontrak internasional terhadap transaksi yang tidak terbatas pada jual bali barang internasional.

Preambul UNIDROIT menegaskan bahwa tujuan prinsip UNIDROIT adalah (Adolf, 2011) :

1. Berupaya menciptakan suatu aturan yang berimbang daharapkan apara aktor perdagangan internasional yang berlatar belakang tingkat ekonomi dan system politik bahkan system hukum yang berbeda dapat menggunakannya.

2. Tujuan lainnya yang juga penting adalah bahwa prinsip UNIDROIT ini dapat digunakan oleh para pihak manakala mereka menemukan jalan buntu dalam menentukan hukum mana yang akan dipilih terhadap kontrak mereka. Kebuntuan ini karenanya dapat diselesaikan dengan kesepakatan para pihak untuk memilih prinsip kontrak UNIDROIT.

3. Prinsip UNIDROIT dapat digunakan oleh para pihak untuk menafsirkan sesuatu hal(klausul) dalam kontrak yang menimbulkan sengketa (karena perbedaan penafsiran) diantara para pihak.

4. Prinsip-prinsip hukum kontrak yang terdapat di dalamnya dapat dimanfaatkan sebagai pegangan bagi para pihak perancang hukum

Copyright @ 2017, LITIGASI, p-ISSN: 0853-7100; e-ISSN: 2442-2274 
Available online at: http://ejournal.unpas.ac.id/index.php/litigasi

dinegara-negara di dunia dalam merancang hukum kontraknya. Bahkan preambulnya juga tidak menutup kemungkinan perjanjian internasional lainnya yang dibuat kemudian setelah adanya prinsip UNIDROIT untuk mengacu kepada prinsip-prinsip kontrak UNIDROIT.

Dalam prinsip-prinsip UNIDROIT terdapat pengaturan penting mengenai kontrak internasional dalam prinsip-prinsip UNIDROIT, yaitu ada 12 prinsip hukum kontrak yang mungkin berguna bagi pembaharuan hukum kontrak di Indonesia saat ini. Kedua belas prinsip hukum tersebut adalah (Soenandar, 2004c) :

1. Prinsip kebebasan berkontrak.

2. Prinsip itikad baik (good faith) dan transaksi jujur (fair dealing).

3. Prinsip diakuinya kebiasaan transaksi bisnis di negara setempat.

4. Prinsip kesepakatan melalui penawaran (offer) dan penerimaan (acceptance).

5. Prinsip larangan bernegosiasi dengan itikad buruk.

6. Prinsip kewajiban menjaga kerahasiaan.

7. Prinsip perlindungan pihak lemah dari syarat-syarat baku.

8. Prinsip syarat sahnya kontrak.

9. Prinsip dapat dibatalkannya kontrak bila mengandung perbedaan besar (gross disparity).

10. Prinsip contra proferentem dalam penafsiran kontrak baku.

11. Prnsip menghormati kontrak ketika terjadi kesulitan (hardship).

12. Prinsip pembebasan tanggung jawab dalam keadaan memaksa (force majeur).

1. Prinsip kebebasan berkontrak.

UNIDROIT bertujuan untuk mengharmoniskan hukum kontrak komersial di negara-negara yang ingin menerapkannya, sehingga materinya difokuskan pada persoalan yang dianggap netral. Dengan

Copyright $\odot$ 2017, LITIGASI, p-ISSN: 0853-7100; e-ISSN: 2442-2274 
demikian ruang lingkup yang diatur oleh prinsip-prinsip UNIDROIT adalah kebebasan berkontrak. Dasar pemikirannya adalah apabila kebebasan berkontrak tidak diatur, dapat terjadi distorsi. Sebaliknya apabila pengaturannya terlalu ketat, akan menghilangkan makna kebebasan berkontrak itu sendiri.

UNIDROIT berusaha mengakomodasi berbagai kepentingan yang diharapkan memberikan solusi persoalan perbedaan system hukum dan kepentingan ekonomi lainnya. Prinsip kebebasan berkontrak diatur dalam Pasal 1.1 UNIDROIT yang diwujudkan dalam 5 bentuk prinsip hukum, yaitu :

a. Kebebasan menentukan isi kontrak;

b. Kebebasan menentukan bentuk kontrak;

c. Kontrak mengikat sebagai undang-undang;

d. Aturan memaksa (mandatory rules) sebagai pengecualian;

e. Sifat internasional dan tujuan prinsip-prinsip UNIDROIT yang harus diperhatikan dalam penafsiran kontrak.

2. Prinsip itikad baik (good faith) dan transaksi jujur (fair dealing)

Landasan utama dari setiap transaksi komersial adalah prinsip itikad baik dan transaksi jujur. Kedua prinsip ini harus melandasi seluruh proses kontrak mulai dari negosiasi sampai pelaksanaan dan berakhirnya kontrak. Pasal 1.7 UNIDROIT menyatakan :

a. Each party must act in accondance with good faith and fair dealing international trade;

b. The parties may not exclude or limit this duty.

Menurut restatement dari pasal di atas ada tiga unsur prinsip itikad baik dan transaksi jujur, yaitu :

a. Itikad baik dan transaksi jujur sebagai prinsip dasar yang melandasi kontrak;

Copyright (C 2017, LITIGASI, p-ISSN: 0853-7100; e-ISSN: 2442-2274 
b. Prinsip itikad baik dan transaksi jujur dalam UNIDROIT ditekankan pada praktik perdagangan internasional;

c. Prinsip itikad baik dan transaksi jujur bersifat memaksa.

3. Prinsip diakuinya kebiasaan transaksi bisnis di negara setempat

Seseorang yang melakukan hubungan hukum kontraktual dengan mitra bisnis di negara lain, dalam praktik harus tunduk pada hukum kebiasaan setempat. Dalam hal ini UNIDROIT memberikan pedoman bagaimana hukum kebiasaan tersebut berlaku.

Ketentuan di atas mengandung enam hal pokok yang perlu diperhatikan, yaitu :

a. Praktik kebiasaan harus memenuhi kriteria tertentu;

b. Praktik kebiasaan yang berlaku di lingkungan para pihak;

c. Praktik kebiasaan yang disepakati;

d. Praktik kebiasaan lain yang diketahui luas atau rutin dilakukan;

e. Praktik kebiasaan yang tidak benar, dan

f. Praktik kebiasaan setempat yang berlaku mengesampingkan aturan umum.

Praktik yang sudah biasa berlaku diantara para pihak secara otomatisakan mengikat para pihak, kecuali apabila mereka sepakat secara tegas untuk mengabaikannya. Kapan suatu praktik kebiasaan dianggap telah berlaku di antara para pihak, hal itu tergantung pada situasi dan kondisi dari setiap kasus.Akan tetapi suatu praktik yang baru satu kali dilakukan dalam transaksi tidaklah cukup dianggap sebagai praktik yang sudah berlaku.Para pihak dapat menegosiasikan segala syarat kontrak termasuk syarat penerapan kebiasaan setempat yang berlaku.

Copyright $\odot$ 2017, LITIGASI, p-ISSN: 0853-7100; e-ISSN: 2442-2274 
4. Prinsip kesepakatan melalui penawaran(offer) dan penerimaan (acceptance) atau melalui prilaku.

Pada prinsipnya kata sepakat dicapai melalui penawaran dan penerimaan. Para penyusun UNIDROIT melihat unsur praktis dari proses terjadinya kontrak. Pasal 2.1. UPICCs menyatakan :

A contract may be concluded either by the acceptance of an offer or by conduct of the parties that is sufficient to show agreement.

Inti dari ketentuan di atas adalah bahwa persetujuan terjadi karena :

1. Penawaran dan penerimaan;

2. Perilaku yang menunjukan adanya persetujuan untuk terikat kontrak.

Dasar pemikiran dari prinsip-prinsip UNIDROIT adalah dengan tercapainya kata sepakat saja sudah cukup untuk melahirkan kontrak.Konsep penawaran dan penerimaan digunakan untuk menentukan apakah dan kapankah para pihak telah mencapai kata sepakat.

5. Prinsip larangan bernegosiasi dengan itikad buruk

Prinsip yang cukup penting diatur dalam prinsip-prinsip UNIDROIT adalah mengenai prinsip itikad baik (good faith)yang berlaku sejak negosiasi. Pasal 2.1.15 UNIDROIT mengatur tentang larangan negosiasi dengan itikad burukdengan menentukan :

1. A party is free to negotiate and is not liable for failure to reach an agreement.

2. However a party who negotiates or breaks off negotiation in bad faith is liable for the losses to the other party.

3. It is bad faith, in particular, for a party to enter into or continue negotiation when intending not to reach an agreement with the other party.

Copyright $\odot$ 2017, LITIGASI, p-ISSN: 0853-7100; e-ISSN: 2442-2274 
Menurut prinsip-prinsip UNIDROIT tanggungjawab hukum telah lahir sejak proses negosiasi.Prinsip hukum yang berlaku bagi proses negosiasi adalah :

1. Kebebasan negosiasi;

2. Tanggungjawab atas negosiasi dengan itikad buruk;

3. Tanggungjawab atas pembatalan negosisasi dengan itikad buruk.

Restatement dari ketiga prinsip di atas mengemukakan bahwa para pihak tidak hanya bebas untuk memutuskan kapan dan dengan siapa melakukan negosiasi. Akan tetapi, juga bebas menentukan kapan, bagaimana, dan untuk berapa lama proses negosiasi dilakukan. Ketentuan ini mengikuti prinsip dasar kebebasan berkontrak dalam Pasal 1.1 sebagai syarat fundamental untuk menjamin adanya persaingan sehat diantara para pihak.

6. Prinsip kewajiban menjaga kerahasiaan

Ketika para pihak melakukan negosiasi, tentu ada rahasia perusahaan yang terbuka dan diketahui oleh kedua belah pihak. Ada kemungkinan mereka memanfaatkan rahasia tersebut untuk keuntungannya. Pasal 2.1.16 mengatur menjaga kerahasiaan. Berdasarkan ketentuan di atas, dapat disimpulkan bahwa para pihak pada dasarnya tidak wajib menjaga rahasia, tetapi ada informasi yang memiliki sifat rahasia, sehingga perlu dirahasiakan dan dimungkinkan adanya kerugian yang harus dipulihkan. Apabila tidak ada kewajiban yang disepakati, para pihak dalam negosiasi pada dasarnya tidak wajib untuk memberlakukan bahwa informasi yang mereka pertukarkan sebagai hal yang rahasia. Dengan kata lain, apabila para pihak bebas menentukan fakta mana yang relevan dengan transaksi yang sedang dinegosiasi, informasi tersebut, dianggap bukan rahasia, yaitu informasi yang pihak

Copyright $\odot$ 2017, LITIGASI, p-ISSN: 0853-7100; e-ISSN: 2442-2274 
lain dapat membukanya kepada orang ketiga atau menggunakannya untuk kepentingan sendiri walaupun kontrak tidak berhasil dibuat.

7. Prinsip perlindungan pihak lemah dalam syarat-syarat baku

Kontrak baku merupakan salah satu sumber dari lex mercatoria. Praktik penggunaan syarat baku telah biasa digunakan dalam dunia bisnis. Pasal $2.19-2.22$ memuat ketentuan tentang syarat-syarat baku tersebut. Pasal 2.19 menentukan :

1. Apabila salah satu pihak atau kedua belah pihak menggunakan syarat baku, maka berlaku aturan umum tentang pembentukan kontrak dengan tunduk pada Pasal 2.20-2.22;

2. Syarat baku merupakan aturan yang dipersiapkan terlebih dahulu untuk dipergunakan secara umum dan berulang-ulang oleh salah satu pihak yang secara nyata digunakan tanpa negosiasi dengan pihak lain.

Pasal ini merupakan pasal pertama dari empat pasal (Pasal 2.19-2.22) yang mengatur tentang keadaan khusus apabila salah satu pihak atau kedua pihak menggunakan syarat baku dalam membuat suatu kontrak.

8. Prinsip dapat dibatalkannya kontrak bila mengandung perbedaan besar (gross disparity)

Prinsip ini pada dasarnya merupakan pelaksanaan dari itikad baik (good faith) dan transaksi jujur (fair dealing) serta prinsip keseimbangan dan keadilan. Hal ini dilandasi adanya kenyataan disparitas yang besar di masyarakat. Oleh karena itu diperlukan adanya aturan yang dapat melindungi pihak yang memiliki posisi yang tidak menguntungkan. Prinsip UNIDROIT mengaturnya dalam Pasal 3.10.

Salah satu pihak dapat membatalkan seluruh atau sebagian syarat individual dari kontrak, apabila kontrak atau syarat tersebut secara tidak

Copyright $\odot$ 2017, LITIGASI, p-ISSN: 0853-7100; e-ISSN: 2442-2274 
sah memberikan keuntungan yang berlebihan kepada salah satu pihak, keadaan demikian didasarkan pada :

1. Fakta bahwa pihak lain telah mendapatkan keuntungan secara curang dan ketergantungan, kesulitan ekonomi atau kebutuhan yang mendesak, atau dari keborosan, ketidaktahuan, kurang pengalaman, kekurangahlian dalam tawar-menawar.

2. Sifat dan tujuan dari kontrak.

Atas permintaan pembatalan kontrak oleh pihak yang berhak, pengadilan dapat mengubah kontrak atau syarat tersebut agar sesuai dengan standar komersial yang wajar dari transaksi yang jujur. Pengadilan dapat juga mengubah seluruh kontrak atau sebagian syaratnya atas permintaan pihak yang menerima pemberitahuan pembatalan. Permohonan harus memberitahu pihak lain tentang permohonannya tersebut.

Unsur adanya kepincangan dari perbedaan yang besar dan mencolok diakibatkan adanya keuntungan yang berlebihan dan keuntungan yang tidak dibenarkan. Hal ini disebabkan oleh :

a. Posisi tawar yang tidak seimbang;

b. Sifat dan tujuan dari kontrak; dan

c. Faktor-faktor lain, sehingga menimbulkan hak untuk membatalkan atau mengubah kontrak tersebut.

Salah satu pihak boleh meminta pembatalan kontrak apabila terjadi perbedaan mencolok (gross disparity) yang memberikan keuntungan berlebihan secara tidak sah kepada salah satu pihak. Keuntungan berlebihan tersebut harus ada pada saat pembuatan kontrak. Suatu kontrak walaupun tidak secara mencolok curang, dapat diubah atau diakhiri berdasarkan ketentuan tentang hardship yang dimuat dalam Bab 6, bagian 2.

Copyright @ 2017, LITIGASI, p-ISSN: 0853-7100; e-ISSN: 2442-2274 
9. Prinsip contra Proferentem dalam penafsiran kontrak baku

Pengaturan penafsiran kontrak diatur dalam bab 4 dengan delapan pasal (Pasal 4.1-4.8.). Dalam buku III KUHPerdata tidak mengatur mengenai penafsiran kontrak, sehingga keberadaannya dapat dijadikan contoh untuk pembaharuan hukum kontrak di Indonesia. Alasannya adalah bahwa ketentuan lain dari penafsiran tersebut pada dasarnya telah diatur dalam hukum positif.

Ketentuan yang cukup penting berkaitan dengan perkembangan lex mercatoria adalah mengenai penafsiran terhadap kontrak baku. Pasal 4.6 mengatur contra proferentem rule menyatakan bahwa jika syarat kontrak yang diajukan oleh salah satu pihak tidak jelas, maka penafsiran yang berlawanan dengan pihak tersebut harus didahulukan.

Para pihak harus bertanggungjawab atas rumusan syarat kontrak, baik rancangan sendiri maupun karena telah mengajukan syarat-syarat terhadap kontrak tersebut.

Cara pemberlakuan aturan ini akan tergantung pada hal-hal sebagai berikut :

a. Keadaan dari kasus yang dihadapi.

b. Sifat kekurangan syarat kontrak yang merupakan pokok objek negosiasi lebih lanjut antara para pihak.

c. Pembenaran untuk menafsirkan syarat itu yang melawan pidak pembuat klausul baku tersebut.

10. Prinsip menghormati kontrak ketika terjadi kesulitan (hardship)

Pasal yang cukup penting dalam Bab pelaksanaan kontrak adalah ketentuan tentang keadaan sulit (hardship). Ketentuan ini dibedakan dengan force majeur yang diatur dalam Bab tentang wanprestasi (non performance).

Copyright $\odot$ 2017, LITIGASI, p-ISSN: 0853-7100; e-ISSN: 2442-2274 
Pengaturan tentang hardship diatur dalam Pasal 6.21 yang menentukan bahwa apabila pelaksanaan kontrak menjadi lebih berat bagi salah satu pihak bagaimanapun jika terikat melaksanakan perikatannya dengan tunduk pada ketentuan tentang kesulitan. Ketentuan ini menentukan dua hal pokok, yaitu :

a. Sifat mengikat dari kontrak sebagai aturan umum, dan

b. Perubahan keadaan yang relevan dengan kontrak jangka panjang.

Tujuan dari ketentuan ini untuk menegaskan sebagai akibat berlakunya prinsip umum tentang sifat mengikat kontrak berdasarkan Pasal 1.3, maka pelaksanaan kontrak harus dijalankan sepanjang hal itu mungin tanpa memperhatikan beban yang dapat dipikul oleh pihak yang melaksanakan. Dengan kata lain walaupun salah satu pihak mengalami kerugian besar atau pelaksanaan kontrak menjadi tidak berarti bagi pihak lain, kontrak bagaimanapun tetap harus dihormati.

Prinsip sifat mengikatnya kontrak bagaimanapun juga bukan suatu yang absolut. Apabila terjadi keadaan yang menimbulkan perubahan fundamental atas keseimbangan dari kontrak, keadaan itu merupakan situasi yang dikecualikan yang dimaksud dalam prinsip ini sebagai "kesulitan". Fenomena kesulitan telah diketahui dalam berbagai system hukum dengan menggunakan istilah lain, tetapi maksudnya sama. Seperti frustation of purfose, wegfall der geschaftsgrundlage, imprevision, accessiva onerosita soprvenuta dan sebagainya. Istilah kesulitan (hardship) dipilih karena secara luas dikenal dalam praktik perdagangan internasional. Sebagaimana diperkuat dengan dimasukkannya di berbagai kontrak internasional yang disebut klausula kesulitan (hardship clauses) (Wiwoho, 2016).

Pasal 6.2.2 memberikan definisi tentang terjadinya kesulitan (hardship) yaitu peristiwa yang secara fundamental telah mengubah keseimbangan kontrak. Hal ini diakibatkan oleh biaya pelaksanaan

Copyright $\odot$ 2017, LITIGASI, p-ISSN: 0853-7100; e-ISSN: 2442-2274 
kontrak meningkat sangat tinggi atau biaya pelaksanaan kontrak bagi pihak yang menerima sangat menurun, sementara itu :

a. Peristiwa itu terjadi atau diketahui oleh pihak yang dirugikan setelah penutupan kontrak;

b. Peristiwa tidak dapat diperkirakan secara semestinya oleh pihak yang dirugikan pada saat penutupan kontrak;

c. Peristiwa terjadi di luar kontrol dari pihak yang dirugikan;

d. Risiko dari peristiwa itu tidak diperkirakan oleh pihak yang dirugikan.

11. Prinsip pembebasan tanggungjawab dalam keadaan memaksa (force majeur)

Wanprestasi adalah gagalnya salah satu pihak untuk melaksanakan setiap kewajiban berdasarkan kontrak, termasuk pelaksanaan yang cacat atau yang terlambat. Definisi wanprestasi mencakup segala bentuk pelaksanaan yang mengandung cacat sampai pada kegagalan pelaksanaan secara total. Contoh wanprestasi, apabila seorang pengembang melakukan pembangunan rumah yang sebagian sesuai kontrak, tetapi sebagian lagi cacat atau lambat penyelesaiannya (Badrulzaman, 1983). Untuk tujuan meletakan prinsip, konsep wanprestasi mencakup wanprestasi yang tidak dimaafkan, (nonexcused) dan yang dimaafkan (excused). Wanprestasi dapat dimaafkan dengan alasan sikap perilaku pihak lain dari kontrak tersebut, atau karena adanya peristiwa eksternal yang tidak diharapkan. Salah satu pihak tidak berhak menuntut ganti kerugian atau pelaksanaan hukum atas wanprestasi yang dimaafkan dari pihak lain. Akan tetapi pihak yang tidak menerima pelaksanaan secara hukum berhak untuk mengakhiri kontrak, baik wanprestasi itu dimaafkan ataupun tidak. Pembatalan ini akan difokuskan pada alasan pemaaf dari wanprestasi karena keadaan

Copyright @ 2017, LITIGASI, p-ISSN: 0853-7100; e-ISSN: 2442-2274 
memaksa. Pasal 7.1.7 mengatur keadaan memaksa dengan menyatakan antara lain sebagai berikut :

1. Wanprestasi yang dilakukan oleh salah satu pihak dapat dimaafkan apabila pihak tersebut dapat membuktikan bahwa wanprestasinya disebabkan oleh suatu rintangan di luar pengawasannya, dan hal itu secara wajar tidak diharapkan akan terjadi.

2. Apabila rintangan hanya bersifat sementara maka pemberian maaf akan berakibat hukum atas jangka waktu dengan memperhatikan akibat dari rintangan pelaksanaan kontrak tersebut.

3. Pihak yang gagal melaksanakan kontrak harus menyampaikan pemberitahuan kepada pihak lain tentang rintangan dan akibat terhadap kemampuannya untuk melaksanakan kontrak. Jika pemberitahuan itu tidak diterima oleh pihak lain dalam jangka waktu yang wajar, setelah pihak yang gagal melaksanakan mengetahui atau seharusnya telah mengetahui adanya rintangan itu ia bertanggungjawab atas kerugian akibat dari tidak diterimanya pemberitahuan tersebut.

4. Pasal ini tidak mencegah salah satu pihak untuk menggunakan haknya mengakhiri kontrak, menahan pelaksanaan kontrak, atau meminta pembayaran bunga atas uang yang telah jantu tempo.

Berdasarkan uraian tersebut di atas, terlihat bahwa prinsipprinsip UNIDROIT banyak mengatur hal-hal yang mana dalam Buku III KUHPerdata belum diatur, ini sebagai upaya dalam mengisi kekosongan hukum guna pembaharuan hukum kontrak yang akan datang, di Indonesia menerapkan prinsip-prinsip hukum kontrak UNIDROIT. Oleh karenanya pengaturan hukum kontrak di masa yang akan datang dapat mengakomodasi berbagai kepentingan, baik pemerintah, masyarakat maupun dunia usaha.

Copyright $\odot$ 2017, LITIGASI, p-ISSN: 0853-7100; e-ISSN: 2442-2274 


\section{B. Persamaan dan perbedaan antara prinsip UNIDROIT dengan prinsip hukum kontrak di Indonesia}

Prinsip-prinsip kontrak internasional UNIDROIT merupakan sumber hukum kontrak internasional guna menciptakan suatu harmonisasi hukum dan aturan-aturan dalam perdagangan internasional, agar segala rintangan dan hambatan dapat diselesaikan. Secara umum prinsip-prinsip hukum kontrak UNIDROIT pada dasarnya memiliki kesamaan dengan hukum kontrak yang berlaku dalam Buku III KUHPerdata di Indonesia, baik dalam tujuan pembentukannya, maupun dalam prinsip pengaturannya.

Dikaji dari kesamaan tujuannya, yaitu bahwa kedua prinsip hukum kontrak yang berlainan teritorial ini diciptakan sebagai upaya untuk memudahkan para pihak melakukan transaksi sekalipun terjadi perbedaan system hukum, system politik dan budaya yang berbeda, mendorong harmonisasi hukum kontrak. Harmonisasi hukum akan terwujud apabila prinsip-prinsip hukum kontrak UNIDROIT maupun system kontrak yang berlaku di Indonesia dapat mendorong terlaksananya tujuan pokok tersebut. Diantara kesamaan yang dimiliki antara prinsip hukum kontrak UNIDROIT dengan Buku III KUHPerdata anrata lain meliputi :

1. Adanya prinsip kebebasan berkontrak. UNIDROIT principle berusaha mengakomodir berbagai kepentingan yang diharapkan memberikan jalan keluar terhadap berbagai persoalan karena perbedaan system hukum maupun sistem ekonomi sebagaimana dalam Pasal 1.1 UNIDROIT yang mengatur prinsip kebebasan berkontrak diwujudkan dalam 5 bentuk prinsip hukum, yaitu kebebasan menentukan isi kontrak, kebebasan menentukan bentuk kontrak, kontrak mengikat sebagai undang-undang, aturan memaksa, sebagai pengecualian, dan sifat internasional dan tujuan prinsip-prinsip UNIDROIT yang harus diperhatikan dalam penafsiran kontrak. Sedangkan dalam Buku III KUHPerdata kebebasan berkontrak diatur dalam Pasal 1338 ayat (1) KUHPerdata mengandung makna

Copyright $\odot$ 2017, LITIGASI, p-ISSN: 0853-7100; e-ISSN: 2442-2274 
bahwa para pihak juga bebas menentukan dengan siapa kontrak akan dibuat, bebas menentukan isi dan syarat kontrak, bebas menentukan bentuk kontrak, bebasan menentukan akan tunduk terhadap hukum mana kontrak dalam Pasal yang dibuat para pihak (Shippey, 2004).

2. Asas itikad baik (good faith). Dalam UNIDROIT diatur dalam Pasal 1.7 bahwa prinsip itikad baik dan transaksi jujur harus melandasi seluruh proses kontrak mulai dari negosiasi, pelaksanaan dan berakhirnya kontrak, "each party act in accordance with good faith and fair dealing in international trade, the parties may not exclude or limit this duty", sedangkan dalam Buku III KUHPerdata diatur dalam Pasal 1338 ayat (3) bahwa perjanjian harus dilaksanakan dengan itikad baik, mengandung konsekuensi bahwa para pihak dalam melaksanakan perjanjian harus berdasarkan kewajaran, dan kepatutan sebagaimana dianut dalam masyarakat.

3. Prinsip kontrak mengikat sebagai undang-undang. Dalam prinsip UNIDROIT diatur dalam Pasal 1.3 bahwa kontrak yang dibuat berdasarkan kata sepakat para pihak mengikat mereka yang membuatnya, "A contract validly into this binding upon the parties. It can only be modified or terminated in accordance with is terms or by agreement or as otherwise provided in this principle", sedangkan dalam KUHPerdata dapat disimpulkan dalam Pasal 1338 ayat (1) yang mengandung makna janji harus ditepati.

4. Prinsip diakuinya praktik kebiasaan dalam transaksi bisnis sebagai hukum pemaksa. Hal ini dapat dilihat dalam prinsip UNIDROIT Pasal 1.8 yang mengandung 6 hal pokok yang perlu diperhatikan, yaitu :

a. Praktik kebiasaan harus memenuhi kriteria tertentu;

b. Praktik kebiasaan yang berlaku dilingkungan para pihak;

c. Praktik kebiasaan yang disepakati;

d. Praktik kebiasaan lain yang diketahui luas atau rutin dilakukan;

Copyright $\odot$ 2017, LITIGASI, p-ISSN: 0853-7100; e-ISSN: 2442-2274 
e. Praktik kebiasaan yang tidak benar;

f. Praktik kebiasaan setempat yang berlaku mengesampingkan aturan umum.

Kapan suatu praktik kebiasaan dianggap telah berlaku, hal ini tergantung pada situasi dan kondisi dari setiap kasus. Di dalam praktik kebiasaan itu haruslah secara umum diketahui dan rutin diterapkan dalam praktik perdagangan nasional maupun internasional. Sedangkan di Indonesia berdasarkan Buku III KUHPerdata, kebiasaan itu mengikat sebagai hukum pemaksa diatur dalam Pasal 1339 jo Pasal 1347 KUHPerdata. Dalam Pasal 1339 KUHPerdata ditegaskan bahwa suatu perjanjian tidak hanya mengikat untuk hal-hal yang dengan tegas dinyatakan di dalamnya, tetapi juga untuk segala sesuatu yang menurut sifat perjanjian diharuskan oleh kepatutan, kebiasaan atau undang-undang, sedangkan dalam Pasal 1347 KUHPerdata bahwa hal-hal yang menurut kebiasaan selamanya diperjanjikan, dianggap secara diam-diam dimasukkan dalam perjanjian meskipun tidak dengan tegas dinyatakan.

Perbedaan antara prinsip UNIDROIT dengan Buku III KUHPerdata terlihat dalam pembentukan suatu kontrak berdasarkan ketentuan UNIDROIT principle yang harus dilakukan melalui penawaran (offer) dan penerimaam (acceptance) yang ditegaskan dalam Pasal 2.1.1 mengenai manner of formation yang berbunyi sebagai berikut : " A contract may be concluded either by the acceptance of an offer or by conduct of the parties that is dufficient to show agreement" Mengenai bagaimana sahnya suatu penawaran dan penawaran tersebut sampai pada pihak yang dituju dan bagaimana penawaran tersebut dapat ditarik kembali. Hal ini dapat dilihat dalam UNIDROIT Pasal 2.1.3 bahwa :

Copyright $\odot$ 2017, LITIGASI, p-ISSN: 0853-7100; e-ISSN: 2442-2274 
1. An offer becomes effectif when it reaches the offere;

2. An offer even if it is irrevocable, may be withdrawn if the withdrawal reaches the offere or at the same time as the offer.

Bagi UNIDROIT syarat pembentukan suatu kontrak melalui penawaran dan penerimaan merupakan syarat mutlak untuk terjadinya kontrak berdasarkan ketentuan UNIDROIT, sedangkan dalam Buku III KUHPerdata di Indonesia, syarat sahnya kontrak telah diatur dalam Pasal 1320 KUHPerdata, bahwa perlu adanya kesepakatan para pihak, terpenuhinya unsur kecakapan para pihak, adanya hal tertentu sebagai objek dan kausa halal. Oleh karenanya berbeda sekali dengan UNIDROIT yang mutlak diperlukan adanya penawaran dan penerimaan dalam kontrak.

Perbedaan lain yang cukup penting antara UNIDROIT dengan Buku III KUHPerdata adalah tentang adanya larangan bernegosiasi dengan beritikad buruk. Menurut prinsip UNIDROIT bahwa jangkauan prinsip itikad baik (good faith) telah berlaku sejak negosiasi, sebagaimana dalam Pasal 2.15 bahwa :

1. A party is free to negotiate and is not liable for failure to reach an agreement.

2. However, a party who negotiates or breaks off negotiation in bad faith is liable for the losses to the other party.

3. It is bad faith, a particular, for a party to enter into or continue negotiation when intending not to reach an agreement with the other party.

Menurut prinsip UNIDROIT tanggung jawab hukum telah lahir sejak proses negosiasi. Hal ini berbeda dengan Buku III KUHPerdata yang hanya mengatur itikad baik hanya dalam pelaksanaan perjanjian, sehingga dalam

Copyright $\odot$ 2017, LITIGASI, p-ISSN: 0853-7100; e-ISSN: 2442-2274 
masa pra kontraktual fungsi itikad baik sangat dibutuhkan sebagaimana UNIDROIT telah mengaturnya.

Perbedaan lain yang juga penting adalah tentang prinsip perlindungan pihak lemah dari syarat-syarat baku, yang diatur dalam Pasal 2.19-2.22 dimana Pasal 2.19 menentukan bahwa :

1. Apabila salah satu pihak atau kedua pihak menggunakan syarat baku, maka berlaku aturan umum tentang pembentukan kontrak dengan tunduk pada Pasal 2.1.20-2.1.22;

2. Syarat baku merupakan aturan yang dipersiapkan terlebih dahulu untuk dipergunakan secara umum dan berulang-ulang oleh salah satu pihak yang secara nyata digunakan tanpa negosiasi dengan pihak lain.

Sedangkan dalam Buku III KUHPerdata hal ini belum ada pengaturannya. Perbedaan lain adalah dalam hal adanya prinsip dapat dibatalkannya kontrak bila mengandung perbedaan besar (hardship). Prinsip ini di dorong oleh adanya pelaksanaan dari prinsip itikad baik dan transaksi jujur serta prinsip keseimbangan dan keadilan. Ini terjadi ketika dalam kontrak terjadi perbedaan yang besar diantara para pihak, sehingga diperlukan adanya pengaturan yang lebih melindungi pihak yang posisi tawarnya tidak menguntungkan. Prinsip UNIDROIT mengaturnya dalam Pasal 3.2.7. Salah satu pihak dapat membatalkan sebagian atau seluruhnya sebagian syarat invidual dari kontrak, apabila kontrak atau syarat tersebut secara tidak sah memberikan keuntungan yang berlebihan kepada salah satu pihak. Hal ini disebabkan oleh :

1. Posisi tawar yang tidak seimbang;

2. Sifat dan tujuan dari kontrak;

3. Faktor-faktor lain, sehingga menimbulkan hak untuk membatalkan atau mengubah kontrak tersebut.

Copyright $\odot$ 2017, LITIGASI, p-ISSN: 0853-7100; e-ISSN: 2442-2274 
Oleh karenanya salah satu pihak dapat dimintakan pembatalan kontrak, apabila terjadi perbedaan mencolok yang memberikan keuntungan berlebihan secara tidak sah kepada salah satu pihak. Sedangkan di Indonesia hal ini belum diatur dalam Buku III KUHPerdata, sebagai sarana perlindungan bagi pihak yang dirugikan.

\section{SIMPULAN DAN SARAN}

\section{A. Simpulan}

1. Kedudukan UNIDROIT sebagai sumber hukum kontrak dalam pembaharuan hukum kontrak Indonesia yang akan datang adalah memiliki posisi yang kuat dan signifikan, karena prinsip-prinsip UNIDROIT merupakan sumber hukum kontrak internasional yang dibuat sebagai upaya menciptakan harmonisasi hukum dan aturan-aturan dalam perdagangan internasional. Diharapkan menjadi akomodasi bagi pembaharuan hukum kontrak Indonesia dimasa yang akan datang, sehingga hal-hal yang belum diatur dalam kontrak Indonesia dapat manjadi input bagi pengembangan kontrak di Indonesia khususnya dan dunia internasional.

2. Persamaan dan perbedaan antara prinsip-prinsip UNIDROIT dengan prinsip hukum kontrak di Indonesia adalah dilihat dari persamaan dapat dikaji dari unsur yang melandasi kontrak, yaitu sama-sama menganut asas kebebasan berkontrak, asan itikad baik (good faith), prinsip kontrak mengikat sebagai undang-undang, dan prinsip diakuinya praktik kebiasaan dalam transaksi bisnis sebagai hukum pemaksa. Sedangkan dari aspek perbedaanya, jelas bahwa dilihat dari teritorialnya berbeda, dimana UNIDROIT berlaku dalam wilayah internasional, sedangkan Buku III berlaku dalam teritorial Indonesia. Dalam UNIDROIT untuk terjadinya kontrak mutlak harus dilakukan penawaran (offer) dan penerimaan (acceptance), adanya larangan bernegosiasi dengan itikad buruk, bahwa

Copyright @ 2017, LITIGASI, p-ISSN: 0853-7100; e-ISSN: 2442-2274 
pada saat pra kontraktual itikad baik pada saat negosiasi sangat diperlukan, karena sering kali dijadikan lahan untuk merugikan pihak lawan. Juga prinsip perlindungan pihak lemah dari syarat-syarat baku sangat penting adanya. Termasuk adanya prinsip dapat dibatalkannya kontrak bila mengandung perbedaan besar yang semuanya belum diatur dalam KUHPerdata bias diakomodir dalam perancangan hukum kontrak yang akan datang di Indonesia.

\section{B. Saran}

1. Oleh karena keberadaan Buku III KUHPerdata sudah tidak memadai dalam memenuhi kebutuhan dan perkembangan masyarakat saat ini, maka perlu melakukan harmonisasi hukum dengan hukum perdagangan internasional dan mengakomodasi ketentuan-ketentuannya yang relevan.

2. Pengaturan hukum kontrak yang baru nanti sebaiknya memuat prinsipprinsip hukum kontrak yang bersifat universal sebagaimana pengaturan dalam UNIDROIT.

Copyright @ 2017, LITIGASI, p-ISSN: 0853-7100; e-ISSN: 2442-2274 


\section{DAFTAR PUSTAKA}

Adolf, H. (2011). Instrumen-Instrumen HukumTentang Kontrak Internasional. Bandung: CV. Kena Media.

Badrulzaman, M. D. (1983). Kitab Undang-undang Hukum Perdata Buku III Tentang Hukum Perikatan Dengan Penjelasan. Bandung: Alumni.

Chandrawulan, A. A. (2016a). Penerapan Prinsip-Peinsip UNIDROIT Dan Konvensi Internasional Terhadap Pembaharuan Hukum Kontrak Indonesia. LITIGASI, 15(1), 2187. https://doi.org/10.23969/litigasi.v15i1.74

Chandrawulan, A. A. (2016b). PENERAPAN PRINSIP-PRINSIP UNIDROIT DAN KONVENSI INTERNASIONAL TERHADAP PEMBAHARUAN HUKUM KONTRAK INDONESIA. LITIGASI, 15(1), 2184. https://doi.org/10.23969/litigasi.v15i1.74

Chandrawulan, A. A. (2016c). PENERAPAN PRINSIP-PRINSIP UNIDROIT DAN KONVENSI INTERNASIONAL TERHADAP PEMBAHARUAN HUKUM KONTRAK INDONESIA. LITIGASI, 15(1), 2185. https://doi.org/10.23969/litigasi.v15i1.74

Chandrawulan, A. A. (2016d). PENERAPAN PRINSIP-PRINSIP UNIDROIT DAN KONVENSI INTERNASIONAL TERHADAP PEMBAHARUAN HUKUM KONTRAK INDONESIA. LITIGASI, 15(1), 2187. https://doi.org/10.23969/litigasi.v15i1.74

Hernoko, A. Y. (2009a). Hukum Perjanjian Atas Proporsionalitas Dalam Kontrak Komersial. Jakarta: Kencana.

Hernoko, A. Y. (2009b). Hukum Perjanjian Atas Proporsionalitas Dalam Kontrak Komersial. Jakarta: Kencana.

Risdiana, Y. (2016). Penafsiran Kontrak Komersial Antara Te3ks dan Konteks Iboeku. Jakarta.

Shippey, K. C. (2004). Menyusun Kontrak Bisnis Internasional Panduan Menyusun Draft Kontrak Bisnis Internasional. Jakarta: PPM.

Soenandar, T. (2004a). Prinsip-prinsip UNIDROIT Sebagai Sumber Hukum Kontrak dan Penyelesaian Sengketa Bisnis Internasional. Jakarta: Sinar Grafika.

Soenandar, T. (2004b). Prinsip-prinsip UNIDROIT Sebagai Sumber Hukum Kontrak dan Penyelesaian Sengketa Bisnis Internasional. Jakarta: Sinar Grafika.

Copyright @ 2017, LITIGASI, p-ISSN: 0853-7100; e-ISSN: 2442-2274 
Available online at: http://ejournal.unpas.ac.id/index.php/litigasi

Litigasi, Vol. 18 (1), 2017,

DOI: http://dx.doi.org/10.23969/litigasi.v18i1.573

Soenandar, T. (2004c). Prinsip-prinsip UNIDROIT Sebagai Sumber Hukum Kontrak dan Penyelesaian Sengketa Bisnis Internasional. Jakarta: Sinar Grafika.

Syaifuddin, M. (2012). Hukum Kontrak, Memahami Kontrak Dalam Perspeftif Filsafat, Teori, Dogmatik, dan Praktik hukum (Seri pengayaan hukum perikatan. Bandung: Mandar Maju.

UUD 1945. Pasal II Aturan Peralihan (1945).

Wiwoho. (2016). Keadilan Berkontrak. Jakarta: Penaku.

Copyright @ ( 2017, LITIGASI, p-ISSN: 0853-7100; e-ISSN: 2442-2274 